\title{
末期腎不全患者における治療法別の身体機能の差異
}

\author{
堀田 千 晴 ${ }^{1}$ 平木 幸治 ${ }^{1}$ 若宮 亜希子 ${ }^{1}$ 井 澤 和 大 $^{2}$

渡辺敏 ${ }^{1}$ 金城 永 幸 $^{3}$ 櫻 田 勉 ${ }^{4}$ 柴 垣 有 吾 4 \\ 木村 健二郎 ${ }^{5}$ \\ 1聖マリアンナ医科大学病院リハビリテーション部 \\ 2聖マリアンナ医科大学内科学講座 ${ }^{3} 川$ 崎市立多摩病院腎臟・高血圧内科 \\ 聖マリアンナ医科大学腎臟・高血圧内科 ${ }^{5} \mathrm{JCHO}$ 東京高輪病院
}

キーワード：慢性腎臓病，身体機能，腹膜透析，血液透析

〈要旨〉

【目的】保存期 (ND), 腹膜透析 (PD), 血液透析（HD）など異なる治療段階が混在する末期腎不全 (ESKD) 患者 を対象に，その治療法別の身体機能の差異を明らかにする.【方法】対象は外来通院中の ESKD 患者 93 例（平均年 齢 66.1 歳, 男性 55 例) である. 対象者は治療法別に ND 群 (36 例), PD 群 (26 例), HD 群 (31 例) の 3 群に選 別した. 患者背景および身体機能指標（膝伸展筋力, 握力, 片脚立位時間, 歩行速度) を横断的に調査し, 各指標 を3 群間で比較した.【結果】 ND 群, PD 群, HD 群の順に, 膝伸展筋力は $0.51 \pm 0.10,0.46 \pm 0.11,0.43 \pm 0.12 \mathrm{kgf} /$ $\mathrm{kg}$, 片脚立位時間は $40.7 \pm 21.0,47.8 \pm 18.1,27.8 \pm 22.6$ 秒，歩行速度は $1.85 \pm 0.28,1.81 \pm 0.37,1.57 \pm 0.34 \mathrm{~m} / \mathrm{s}$ で あり，3 群間に主効果を認めた。ささらに HD 群は他の群と比し，己れら指標が有意に低值を示した $(p<0.05)$. 方握力は, 3 群間に有意差を認めなかった $(p=0.62)$.【結語】 ESKD 患者では, HD 患者において身体機能が有意 に低下していた。

\section{The differences in the physical function levels of end-stage kidney dis- ease patients according to the therapeutic modalities employed}

Chiharu Hotta ${ }^{1}$, Koji Hiraki', Akiko Wakamiya', Kazuhiro P. Izawa², Satoshi Watanabe', Nagayuki Kaneshiro ${ }^{3}$, Tsutomu Sakurada ${ }^{4}$, Yugo Shibagaki ${ }^{4}$, Kenjiro Kimura ${ }^{5}$

${ }^{1}$ Department of Rehabilitation Medicine, St. Marianna University School of Medicine Hospital; ${ }^{2}$ Department of Internal Medicine, St. Marianna University School of Medicine; ${ }^{3}$ Division of Nephrology and Hypertension, Kawasaki Municipal Tama Hospital; ${ }^{4}$ Division of Nephrology and Hypertension, Department of Internal Medicine, St. Marianna University School of Medicine; ${ }^{5}$ Japan Community Health care Organization Tokyo Takanawa Hospital

Keywords: chronic kidney disease, physical function, peritoneal dialysis, hemodialysis

〈Abstract〉

【Purpose】The purpose of this study was to investigate the differences in the physical function levels of patients with end-stage kidney disease (ESKD) according to the therapeutic modalities employed.【Methods】 The study population comprised 93 patients with ESKD (mean age, 66.1 years; 55 males). The patients were divided into three groups according to the therapeutic modality that they were treated with: the non-dialysis (ND) (36 patients), peritoneal dialysis (PD) (26 patients), and hemodialysis (HD) (31 patients) groups. The patients' background data and physical function indices (knee extensor muscle strength, handgrip strength, one-leg standing time, and gait speed) were investigated and compared among the three groups.【Results】 In the ND, $\mathrm{PD}$, and $\mathrm{HD}$ groups, knee extensor muscle strength values of $0.51 \pm 0.10,0.46 \pm 0.11$, and $0.43 \pm 0.12 \mathrm{kgf} / \mathrm{kg}$; oneleg standing times of $40.7 \pm 21.0,47.8 \pm 18.1$, and $27.8 \pm 22.6 \mathrm{sec}$; and gait speeds of $1.85 \pm 0.28,1.81 \pm 0.37$, and

堀田 千晴 聖マリアンナ医科大学病院リハビリテーション部７ 216-8511 神奈川県川崎市宮前区菅生 2-16-1

Chiharu Hotta Tel: 044-977-8111 Fax: 044-977-9486

〔受付日：2016 年 7 月 14 日, 受理日：2017 年 2 月 9 日〕 
$1.57 \pm 0.34 \mathrm{~m} / \mathrm{sec}$, respectively, were recorded. The HD patients exhibited significantly lower values for these indices compared with the other two groups $(p<0.05)$. However, there was no significant difference in handgrip strength among the three groups $(p=0.62)$.【Conclusions】 This study clearly showed that among patients with ESKD, only those undergoing HD displayed reduced physical function levels.

\section{緒言}

本邦の慢性腎臟病 (chronic kidney disease: CKD) 患者は約 1,330 万人, うち透析患者は 2014 年に 32 万 人に達し，増加傾向にある ${ }^{1)}$. CKD は心血管疾患の発 生リスクが高く, CKD が悪化し維持血液透析（hemodialysis: HD）に移行した場合，患者の身体活動量や身 体機能は低下する ${ }^{2,3)}$.さらにそれらは，日常生活動作 (activities of daily living: ADL) や quality of life （QOL）低下へつながることから，CKD 進行予防は急 務の課題である.

一方, 身体機能は ADL や QOL に関連する要因の一 つである ${ }^{4)}$. 先行研究より CKD 患者の身体機能は, 健 常者に比し低值を示すと報告されている5

Matsuzawa $ら^{6)}$ は，本邦の HD 患者における滕伸展 筋力は生命予後と関連することを報告した。このこと から，身体機能は HD 患者の重要な指標の一つといえ る．しかし CKD 患者に関する報告の多くは，対象者 が HD 患者のみであり，保存期や腹膜透析（peritoneal dialysis: PD）患者に関する報告は少ない，そこでわれ われは，保存期 CKD や PD 患者の身体機能の害態に ついて調查し, 保存期 CKD 患者はステージ進行に伴 い身体機能が低下する7) ことや, PD 患者の膝伸展筋力 は健常者に比し低下している ${ }^{8)}$ こを報告した。しか し，これまで保存期，PD，HD といった異なる治療患 者を対象とし，身体機能の差異を調査した報告は少な い.また，末期腎不全（end-stage kidney disease: ESKD）患者の治療法別での身体機能の差異について は不明である．治療法別の身体機能の差異を明らかに することは，治療段階に応じた運動指導方法を検討す る一助となり，早期運動介入を促す動機づけにもつな がる可能性がある.

本研究の目的は, 保存期, PD, HD という異なる治 療段階の ESKD 患者において, 治療法別の身体機能の 差異を明らかにすることである。

\section{I．対象および方法}

\section{1. 対 象}

対象は 2011 年 3 月〜2014 年 3 月まで, 聖マリアン ナ医科大学病院または川崎市立多摩病院の, 腎臟高血
圧内科に外来通院中の ESKD 患者 93 例である. 取り 込久基準は，透析を導入していない推算糸球体滤過量 (estimated glomerular filtration rate: eGFR) $15 \mathrm{~mL} /$ $\mathrm{min} / 1.73 \mathrm{~m}^{2}$ 未満の保存期 $\mathrm{CKD}$ 症例， および $\mathrm{PD}$ また は HD の透析期 CKD 症例である。除外基準は，腎移 植患者, PD および HD を併用している症例, 歩行に 介助を要する症例，認知症例，骨関節疾患または中枢 神経疾患により麻痺をきたしている症例である。

われわれは対象者を治療法別に，腎代替療法を行っ ていない保存期群 (non-dialysis: ND 群), 腹膜透析を 施行している群 (PD 群), 維持血液透析を施行してい る群（HD 群）の 3 群に選別した.

\section{2. 倫理的配慮}

本研究は, 聖マリアンナ医科大学生命倫理委員会の 承認を得て実施した（承認番号第 多 154 号)。対象 者には研究の趣旨, 内容, および結果の取り扱い等に 関し説明し同意を得た。

\section{3. 調査・測定項目 \\ 1）患者背景}

患者背景は, 年齢, 性別, body mass index (BMI), 原疾患，糖尿病の有無，PD および $\mathrm{HD}$ 施行患者は透 析期間, 血液生化学検查值（ND 群のみ $\mathrm{eGFR}$, 血清 ヘモグロビン $[\mathrm{Hb}]$, 血清アルブミン $[\mathrm{Alb}])$ である. これらの指標は，後述する身体機能を測定した同一日 またはその直近の值を，診療記録より後方視的に調查 した。

\section{2）身体機能指標}

(1) 膝伸展筋力

下肢筋力の指標は, 等尺性滕伸展筋力を採用した. 測定は Hand Held Dynamometer (ANIMA 社製， $\mu-$ TasMF- $01^{\circledR}$ ) と固定ベルトを用い, 被検者が端座位か つ下腿下垂位，両上肢は体幹前方で組んだ肢位で，先 行研究7)に準じ行った。検者は約 5 秒間の最大努力に よる等尺性滕伸展運動を行うよう指示し, 左右 2 回ず つ測定した，その左右の最大值の平均值を，体重で除 した值 $(\mathrm{kgf} / \mathrm{kg})$ が, 膝伸展筋力として採用された. (2) 握力

上肢筋力の指標は，握力である．握力は油圧式握力 計 (Sammons Prestons 社製, Jamar $^{\circledR}$ Hand Dynamometer-5030J1)にて測定された. 先行研究に準じ7), 測定肢位は座位かつ肘関節屈曲 $90^{\circ}$, 前腕中間位とし た. 左右 2 回ずつ測定し, 左右の最大值の平均值 (kgf) 
表 1 治療法別の患者背景の比較

\begin{tabular}{|c|c|c|c|c|}
\hline & $\begin{array}{c}\text { ND 群 } \\
\text { 保存期群 } \\
(\mathrm{n}=36)\end{array}$ & $\begin{array}{c}\mathrm{PD} \text { 群 } \\
\text { 腹膜透析群 } \\
(\mathrm{n}=26)\end{array}$ & $\begin{array}{l}\text { HD 群 } \\
\text { 血液透析群 } \\
(\mathrm{n}=31)\end{array}$ & $p$ 値 \\
\hline 年齢（歳） & $66.0 \pm 9.9$ & $65.9 \pm 9.4$ & $66.5 \pm 9.7$ & 0.97 \\
\hline 性別（男/女） & 24/12 & $15 / 11$ & $16 / 15$ & 0.45 \\
\hline BMI $\left(\mathrm{kg} / \mathrm{m}^{2}\right)$ & $23.2 \pm 3.7$ & $23.0 \pm 3.1$ & $21.6 \pm 3.4$ & 0.12 \\
\hline 原疾患（症例数） & & & & 0.07 \\
\hline 糖尿病 & 9 & 7 & 12 & \\
\hline 腎硬化症 & 11 & 2 & 7 & \\
\hline 糸球体腎炎 & 4 & 5 & 1 & \\
\hline 多発性囊胞腎 & 5 & 2 & 1 & \\
\hline その他 & 3 & 3 & 0 & \\
\hline 不明 & 4 & 7 & 10 & \\
\hline 糖尿病割合（\%） & 38.9 & 23.1 & 38.7 & 0.36 \\
\hline 透析期間（か月）※ & - & $14.5(4.5 \sim 24.5)$ & $40.0(14.5 \sim 65.5)$ & $<0.01$ \\
\hline eGFR $\left(\mathrm{mL} / \mathrm{min} / 1.73 \mathrm{~m}^{2}\right)$ & $11.0 \pm 2.4$ & - & - & \\
\hline $\mathrm{Hb}(\mathrm{g} / \mathrm{dL})$ & $10.1 \pm 1.0$ & $10.7 \pm 0.9$ & $10.9 \pm 1.1$ & $<0.01^{*}$ \\
\hline $\operatorname{Alb}(\mathrm{g} / \mathrm{dL})$ & $3.8 \pm 0.3$ & $3.7 \pm 0.4$ & $3.8 \pm 0.3$ & 0.63 \\
\hline
\end{tabular}

※：透析期間は Mann-Whitney の U 検定結果, 中央值（四分位範囲）を示す.

ほか指標は, 一元配置分散分析結果, 平均值士標準偏差を示す.

$\mathrm{ND}$ : 保存期, PD : 腹膜透析, HD : 血液透析, BMI : body mass index, eGFR : estimated glomerular filtration rate, Hb : ヘモグロビン, Alb : 血清アルブミン

* : 保存期群 vs. 血液透析群 $(\mathrm{p}<0.05)$

を採用した。

(3) 片脚立位時間

バランス能力の指標は, 片脚立位時間を採用した. 検者は，開眼にて上肢支持を用いずに片側下肢を挙上 するよう指示し，上肢や骨盤が手すりに触れる，また は支持側以外の下肢が床に触れるまでの時間を 2 回計 測した. 左右の最高值の平均值を片脚立位時間とし た。測定時間の上限は 60 秒とした。

(4) 歩行速度

歩行能力の指標は，最大歩行速度を用いた．測定は 助走路を設け，計測開始地点のテープを越えた接床か ら $10 \mathrm{~m}$ 先のテープを越えた接床までの時間を測定し た. 歩行はできるだけ速く歩くよう指導した. 2 回計 測したうち，時間の短い記録から速度 $(\mathrm{m} / \mathrm{s})$ を算出 した。

\section{4. 統計処理}

患者背景における治療法別の 3 群間の比較には, 性 別, 原疾患, 糖尿病割合には $\chi^{2}$ 検定, $\mathrm{PD}$ および $\mathrm{HD}$ 群の透析期間の比較には Mann-Whitney の U 検定, その他の指標には一元配置分散分析 (多重比較は Turkey 法）を用いた。一方，身体機能指標の比較は，身 体機能に影響を与えうる交絡因子（年齢，性別，糖尿 病の有無）を共変量とした共分散分析を用い，比較し た. 解析は, SPSS 12.0 J (SPSS Japan, Inc, Tokyo, Japan）を用いた. 統計学的有意判定の基準は, $5 \%$ 未 満とした。

\section{II. 結 果}

\section{1. 患者背景}

全症例の平均年齢は $66.1 \pm 9.6$ 歳, 男性が $59.1 \%$, 糖 尿病割合は $34.4 \%$ であった，表 1 に治療法別の患者背 景を示す。年齢, 性別, BMI, 原疾患, 糖尿病割合, Alb は, 3 群間に有意差を認めなかった。 Hb は ND 群 が HD 群に比し，低值を示した $(\mathrm{p}<0.01)$ 。透析期間 は, PD 群が HD 群に比し低值を示した（p<0.01）.

\section{2. 身体機能指標}

表 2 に治療法別の身体機能を示す. 膝伸展筋力, 片 脚立位時間，歩行速度は，3群間に主効果を認めた $(\mathrm{p}<0.05)$. 多重比較による各指標の比較では, 膝伸展 筋力は ND 群が PD 群および HD 群に比し, 高值を示 した（ $\mathrm{p}=0.04, \mathrm{p}<0.01)$. 片脚立位時間は， ND およ び PD 群が HD 群に比し，高值を示した $(\mathrm{p}<0.01)$. 歩行速度も同様に, ND および $\mathrm{PD}$ 群が $\mathrm{HD}$ 群に比し, 高值を示した $(\mathrm{p}<0.01)$. しかし, 握力は 3 群間に差 を認めなかった（p=0.62）.

\section{III. 考察}

本研究の目的は，ESKD 患者における治療法別の身 体機能の差異を明らかにすることであった．その結 果, HD 患者は ND 患者および PD 患者に比し, 多く 


\begin{tabular}{lccccc}
\hline & $\begin{array}{c}\mathrm{ND} \text { 群 } \\
\text { 保存期群 } \\
(\mathrm{n}=36)\end{array}$ & $\begin{array}{c}\mathrm{PD} \text { 群 } \\
\text { 腹膜透析群 } \\
(\mathrm{n}=26)\end{array}$ & $\begin{array}{c}\mathrm{HD} \text { 群 } \\
\text { 血液透析群 } \\
(\mathrm{n}=31)\end{array}$ & $\mathrm{F}$ 值 & $p$ 值 \\
\hline 膝伸展筋力 $(\mathrm{kgf} / \mathrm{kg})$ & $0.51 \pm 0.10$ & $0.46 \pm 0.11$ & $0.43 \pm 0.12$ & 4.5 & $0.01^{* * * *}$ \\
握力 $(\mathrm{kgf})$ & $25.6 \pm 6.7$ & $24.4 \pm 9.8$ & $22.9 \pm 5.8$ & 0.5 & 0.62 \\
片脚立位時間 (秒) & $40.7 \pm 21.0$ & $47.8 \pm 18.1$ & $27.7 \pm 22.6$ & 7.2 & $<0.01^{* * * * *}$ \\
歩行速度 $(\mathrm{m} / \mathrm{s})$ & $1.85 \pm 0.28$ & $1.81 \pm 0.37$ & $1.57 \pm 0.34$ & 7.0 & $<0.01^{* * * * *}$ \\
\hline
\end{tabular}

平均值土標準偏差を示す。共変量 : 年齢, 性別, 糖尿病有無

$\mathrm{ND}:$ 保存期, $\mathrm{PD}$ : 腹膜透析, $\mathrm{HD}:$ 血液透析

* : 保存期群 vs. 血液透析群 $(\mathrm{p}<0.05),{ }^{* *}$ : 保存期群 vs. 腹膜透析群 $(\mathrm{p}=0.04)$,

*** : 腹膜透析群 vs. 血液透析群 $(\mathrm{p}<0.01)$

の身体機能指標が低下していた。

\section{1. 治療法別の 3 群間における差異}

Mclntyre ら ${ }^{9)}$ は CKD ステージ 4, PD および HD 患 者において筋横断面積と身体機能 (sit-to-stand 60 test）を調查した。 その結果，筋横断面積および身体 機能は, CKD ステージ 4 患者が PD および $\mathrm{HD}$ 患者と 比較し有意に高值であったが，PD患者と HD 患者に おいて有意差は認めなかったと報告している，本研究 では PD 群が HD 群と比較し身体機能は高かったこと から，異なる結果となった。 その理由として，透析期 間の影響が考えられる。前述の先行研究では PD およ び HD 患者において透析期間に差はなかったものの, 本研究では PD 患者が HD 患者と比較し，有意に透析 期間が短かった。齊藤ら ${ }^{10)}$ は，HD患者において透析 期間の長期化は, 身体機能低下の要因の一つであると 報告している。よって，透析期間が長期にわたる場合 は，身体機能低下を危惧する必要があると考える。そ れ以外に HD 患者の身体機能低下の要因には，低栄 養, 低活動, 貧血, 骨格筋萎縮, 炎症, 心血管疾患の 合併等がある ${ }^{11,12)}$ 。本研究の患者背景の比較より, HD 群は ND 群や PD 群に比し, Hb は高值であり, 栄養指 標である Alb は有意差を認めなかった.このことから HD 患者の身体機能低下の要因を, 貧血や栄養状態に 帰することはできず, ほかの要因の影響が考えられ た。一方，ND群と PD 群における身体機能の比較で は，膝伸展筋力においてのみ有意差を認めたものの, その他の指標は有意差を認めなかった. これは PDの 利点である，拘束時間が少なくライフスタイルが保た れやすいこと, HD 後のような倦怠感が少ないこと等 の影響が考えられる．以上より，透析方法としては $\mathrm{PD}$ が HD と比較し身体機能を維持しやすい可能性が 考えられる。

身体機能は身体活動量と関連することは知られてい る ${ }^{13)}$ 。本邦 CKD 患者における歩数計を用いた身体活 動量の実態について, 保存期 CKD stage 4-5 患者の平
均歩数は 5,870 歩/日 ${ }^{14)}, \mathrm{PD}$ 患者は 4,864 歩/日 ${ }^{15)}, \mathrm{HD}$ 患者は 3,266 歩/ ${ }^{16)}$ と報告されている. これら先行研 究の患者背景は異なるため単純比較はできない.しか し, これら先行研究は本研究結果と同様に, 保存期, $\mathrm{PD}, \mathrm{HD}$ 患者の順に身体活動量が低下する傾向を示し ている．このことから， ESKD 患者は治療変更により ライフスタイルが変化し，身体活動量のみならず，身 体機能低下にまで影響した可能性がある。よって今後 は，身体機能に加え身体活動量を含めた介入方策の検 討が必要である。

一方，握力は 3 群間に有意差を認めなかった． 握力 はサルコペニアやフレイルの判別に用いられる指標で ある ${ }^{17)}$. しかし，身体機能の変化を鋭敏にとらえる指 標としては不向きであり，下肢筋力や身体活動評価の ほうが重要な指標である可能性が示唆された。

膝伸展筋力は ADL 動作と強く関連する ${ }^{18)}$. 動作が 全例自立する膝伸展筋力水準は, 階段動作が $0.50 \mathrm{kgf} /$ $\mathrm{kg}$, 歩行動作が $0.40 \mathrm{kgf} / \mathrm{kg}$ であると報告されてい $ろ^{18)}$.つまりこの水準以下の場合, これらの動作が安 全に遂行可能な確率が減少する。この水準と本研究結 果を比較すると, PD 群と HD 群の膝伸展筋力は階段 動作の自立水準を下回り, ND 群においても階段動作 の自立水準と近似するレベルであることから， ADL に支障をきたす水準まで下肢筋力は低下していること が示された. よって，腎代替療法を行う患者ではすで に ADL 障害発生のリスクが高い状態であると思われ る.エビデンスに基づく CKD 診療ガイドライン $2009^{19)}$ は, 「肥満の是正, 糖尿病新規発症の予防, 高血 圧の治療，CVD 発症予防のために身体活動度を維持 すべき」としている. しかし，ADL 障害レベルまで下 肢筋力が低下した場合, 身体活動を維持することが困 難となっている可能性がある，以上より，われわれは 個々の症例に応じ身体機能および ADL を評価し，身 体機能向上を目的とした筋力トレーニングを処方する ことも考慮すべきと考える. 


\section{2. 本研究の臨床的意義}

本研究結果より，ESKD 患者は HD 治療に至る段階 ではすでに ADL 障害をきたすリスクが高い実態が明 らかとなった。ゆえに, より早期の段階から介入につ いて検討する必要がある。この実態は ESKD患者にお いて, 運動療法への関心を惹起し, 運動を始める動機 づけの一助になる可能性がある.

\section{3. 研究の限界}

本研究は横断研究のため, 身体機能低下の要因や腎 代替療法の影響については不明である。また PD およ びHD 患者における比較では，透析期間の影響を調整 できていないことから，これが身体機能の差異に影響 している可能性がある. 今後は, 縦断的な調査が必要 であるとともに身体機能低下要因の解明には，身体活 動量や就労実態および心機能など調査指標を増やして の検討が必要である。また各群の症例数が少ないた め, 症例数を増やす必要がある.さらに本研究対象者 は，全例が歩行可能な者であるため，本研究結果を歩 行が困難な虚弱な者へ用いる場合は注意が必要である.

\section{結 論}

ESKD 患者において，HD 患者は保存期および PD 患者に比し身体機能は低かった。一方, 保存期 CKD 患者と PD 患者は，膝伸展筋力以外の身体機能に差は なかった.

利益相反：本研究に関連する，開示すべきCOI 関係にあ る企業等は以下のとおりである.

講演料：大日本住友製薬，帝人ファーマ，第一三共（共 同著者 : 木村健二郎), 原稿料 : 南江堂（共同著者：木村健 二郎)，研究費および助成金：武田薬品工業，アストラゼネ 力, 塩野義製薬, 協和発酵キリン, 田辺三菱製薬, アステ ラス製薬（共同著者：柴垣有吾).

\section{文献}

1）日本腎臓学会編．CKD 診療ガイド 2012. 東京：東京 医学社, 2012.

2) Johansen KL, Chertow GM, Ng AV, et al. Physical activity levels in patients on hemodialysis and healthy sedentary controls. Kidney Int 2000; 57 : 2564-70.

3) Johansen KL, Kaysen GA, Young BS, Hung AM, da Silva M, Chertow GM. Longitudinal study of nutritional status, body composition, and physical function in hemodialysis patients. Am J Clin Nutr 2003; 77 : 842-6.
4）植屋清見，小山慎一. 文部科学省新体力テストに関す る高齢者の体力・ADL・QOL と日常生活実態の関連. 帝京科学大学紀要 2011；7：25-34.

5) Padilla J, Krasnoff J, Da Silva M, et al. Physical functioning in patients with chronic kidney disease. J Nephrol 2008; 21: 550-9.

6) Matsuzawa R, Matsunaga A, Wang G, et al. Relationship between lower extremity muscle strength and all-cause mortality in Japanese patients undergoing dialysis. Phys Ther 2014; 94: 947-56.

7) Hiraki K, Yasuda T, Hotta C, et al. Decreased physical function in pre-dialysis patients with chronic kidney disease. Clin Exp Nephrol 2013; 17: 225-31.

8）堀田千晴, 平木幸治, 若宮业希子, 他. 腹膜透析患者 における滕伸展筋力の実態とその関連要因の検討．臨 牀透析 2014；30：359-63.

9) Mclntyre CW, Selby NM, Sigrist M, Pearce LE, Mercer TH, Naish PF. Patients receiving maintenance dialysis have more severe functionally significant skeletal muscle wasting than patients with dialysisindependent chronic kidney disease. Nephrol Dial Transplant 2006；21：2210-6.

10）齊藤正和, 松永篤彦, 横山美佐子, 福田倫也, 吉田煦, 増田卓. 透析期間の長期化が血液透析患者の運動機能 に及ぼす影響について，透析会誌 2007；40：147-53.

11) Painter P. Physical functioning in end-stage renal disease patients: update 2005. Hemodial Int 2005; 9: $218-35$.

12) Johansen KL, Chertow GM, da Silva M, Carey S, Painter P. Determinants of physical performance in ambulatory patients on hemodialysis. Kidney Int 2001; 60: 1586-91.

13) Brach JS, FitzGerald S, Newman AB, et al. Physical activity and functional status in community-dwelling older women: a 14-year prospective study. Arch Intern Med 2003; 163: 2565-71.

14）若宮亜希子, 平木幸治, 堀田千晴, 他. 保存期慢性腎 臓病患者の身体活動量の実態. 理学療法学 2013; 40 (Suppl. 1)：161.

15）若宮亜希子, 平木幸治, 堀田千晴, 他. 腹膜透析患者 の身体活動の実態調查. 理学療法学 2013；40：473-9.

16）森素子, 水上薰, 渡邊まさ子, 他：血液透析患者の身 体活動性について．透析会誌 2001；34：1239-40.

17) Cruz-Jentoft AJ, Baeyens JP, Bauer JM, et al,; European Working Group on Sarcopenia in Older People. Sarcopenia: European consensus on definition and diagnosis: Report of the European Working Group on Sarcopenia in Older People. Age Ageing 2010; 39: 412-23.

18）山崎裕司, 長谷川輝美, 横山仁志, 他. 等尺性膝伸展 筋力と移動動作の関連一運動器疾患のない高齢患者を 対象として。総合リハ 2002；30：747-52.

19）日本腎臓学会編. エビデンスに基づく CKD 診療ガイ ドライン 2009. 東京：東京医学社， 2007. 